\title{
Authors, Publishers and Readers of Popular Literature in Latvia in the Late 1980s and Early 1990s
}

\author{
JANA DREIMANE
}

\begin{abstract}
The purpose of the present article is to determine changes in book publication and reading habits in Latvia from the end of the 1980s onwards - a period characterized by the gradual shrinkage of the dictate of state authorities and political censorship, Latvia regaining independence in 1990 and the first years of the independent republic (up to 1995) involving the transition from the centrally planned economy to the free market economy, when the publishing houses which were established in Soviet times made attempts to pursue new development paths, whereas the newly-established ones tried to put down their roots in the publishing business.
\end{abstract}

Keywords: Latvian book history, book publishing, popular literature, detective novels, romance novels

\section{Introduction}

Popular literature (popular literature, genre fiction; in German - populäre Literatur) is part of popular (or mass) culture which is equally consumed by diverse social groups, irrespective of age, educational background, occupation, income level, beliefs and other factors. It, beyond doubt, includes most published, purchased and read pieces of literature. Thus, popular literature consists of high circulation reprints found on the best-selling books lists. ${ }^{1}$ Characteristic elements of popular literature are: serialization and low price - even till the second half of the $20^{\text {th }}$ century popular literature was mostly found in the form of continued publications in general or literary periodicals (due to this, the text was structured in rather short chapters each of which ended with some intriguing detail to make the readers interested in the forthcoming), serialized

1 During the totalitarian regime, i.e.in the Soviet Latvia (1944-1990) when the publishing process - the contents, choice, number of copies, book selling scheme and distribution of profit was determined by state institutions, these indicators did not reflect the actual consumption. However, sociological studies on reading habits were conducted in Latvia in the 1970s and 1980s, considerably contributing to understanding the overall picture of reading habits. 
thin booklets or pocket books the most vivid element of which was the bright and showy cover. Commonly books belonging to the same series had the same price. The cheap, low-quality books initially were distributed by street vendors or colporteurs. Today they have gained a stable place on the shelves of bookstores (Bloom 2002: 69).

Numerous researchers emphasize the entertainment function of popular culture, including literature, therewith classifying it among the forms of 'low culture'. However there is no homogeneity in the quality of popular literature as it comprises utterly clichéd works with a predictable narrative structure and character system which is repeated over and over again and also masterpieces dealing with topical contemporary issues executed in a creative and captivating form. So for example, popular literature includes the novel Oliver Twist by the English writer Charles Dickens (1812-1870) which contains elements of crime fiction, dramatic tension carried by the plot and a happy ending. Similarly to numerous other popular novels of that time, initially the novel was a serial publication in the literary magazine Bentley's Miscellany (1837-1838) whose first editor was Dickens. For the first time in English literature the central plot of a novel dealt with the destiny of a poor, parentless child. The novel depicts vulnerability and lack of rights of orphans which leads to crime as the single means of survival. The novel stirred public discussion on the social care of the poor, especially orphans (Schlicke 2000).

The connection between popular literature and mass media (TV, cinema, radio, printed press) is also important. Quite often a popular novel is adapted into a stage version or a screenplay, gaining immense popularity among theatre or filmgoers or vice versa - the contents of popular movies or soap operas are offered to the readers in the form of a story or a novel.

Local and also foreign studies show that the novel is the most popular literary genre ${ }^{2}-$ the first rank is occupied by detective and romance novels (accounting for 50-60\% of the most distributed books) (Glover, McCracken 2012: 27; Bloom 2002: 85).

This research deals with two types of novels - detective and romance novels printed in book form in Latvia in the period from 1986 to 1995 . The article will identify the most popular authors and their works, likewise the publishing houses specializing in the publication of this particular form of literature. Book publishing dynamics, the available rankings of best-selling books according to

According to a unpublished study conducted by the National Library of Latvia Dailliteratūras lasī̌sana 1985.-1987. (Fiction reading habits in 1985-1987), novels were read by $38.3 \%$ of the population although it was not the most highly rated literary genre. 
DREIMANE

the periodical Grāmatu Apskats (Book Review) and discussions in mass media allow to draw conclusions on the assessment of popular literature in Latvia.

The study has been developed on the basis of the collection of the publishing house Liesma kept by the State Archive of Latvia, thematic plans of publishing houses published till 1990, publications dealing with book printing and also the reviews of the State Chamber of Books of the Latvian S.S.R. (from December 1989 to the foundation of the Institute of Bibliography which was merged with the National Library of Latvia in October 1993 and is functioning as a separate Department) on books and pamphlets published from 1986 to 1995. The study is based upon statistical data analysis and content analysis of different sources.

\section{Gaps between public demand and publishers' offer}

In the second half of the 1980s the gap between what was offered by publishing houses and public demand had become self-evident. Fiction was published by three publishing houses (Avots, Zvaigzne, Liesma) and also by the publishing house Zinätne maintained by the Academy of Sciences of the Latvian S.S.R. (Latvijas PSR Prese 1987: 3). Out of the entire range of books and pamphlets published in the second half of the 1980 s, fiction composed only $8-10 \%$, i.e. about two hundred publications (161 titles or $8.4 \%$ in 1989). The majority thereof (about 90\%) were published by the specialized publishing house Liesma, up to ten books for school age children were provided by the textbook publisher Zvaigzne, whereas the publishing house Zinatne offered works of Latvian literary classics with foreword, afterword and scientific comments. Prose made up over half of the shelved fiction works (146 in 1986; 137 in 1987 and 108 in 1988), thus only few of the offered publications could be classified as popular literature. The majority were the works of well known authors. For example, eight publications of the Latvian detective novelist and scriptwriter Andris Kolbergs (1938) in Latvian and Russian were released from 1985 till 1989 , amounting to 890,000 copies in total. A sociological study conducted by the National Library of Latvia on fiction reading habits in years 1985-1987 (Dailliteratūras lasī̌̌ana 1985.-1987.) demonstrates that Kolbergs was among the most read novelists in Latvia - his novels Naktī, lietū... (At Night, in the Rain...) and Automobìlì rìta pusē (In an Automobile, in the Morning) had been read by almost $74.5 \%$ of Latvian respondents (Purina 1992: 16) and by $68 \%$ of the surveyed Russian-speaking readers (Hofmane 1992: 36).

The Latvian reader was eager to explore foreign popular literature which was scarcely available. Two romance novels which were published in 1987 and 
Authors, Publishers and Readers of Popular Literature in Latvia

1988 were on the most wanted list. So, after a break which lasted for almost half a century, the best-seller Gone with the Wind (Latvian title Vejjiem lìdzi) by the American writer Margaret Mitchell (1900-1949) was presented to the local readers in 100,000 copies by the publishing house Liesma. The publication was based upon the first Latvian edition (publishing house Grāmatu Draugs, 1938) prepared by the writer and translator Valdemārs Kārkliņš (1906-1964). It was planned to be published in Soviet Latvia already in 1962, however the book saw the light only a quarter of a century later. People formed incredibly long queues in front of bookstores and mass media stirred discussion on the inability of publishing houses to adapt to the public demand (Cīna 1987; Brīvā Latvija 1987). Although it was obvious that an additional edition would be more than welcome, the publisher rejected it, since the available funding was required for other books. ${ }^{3}$

The poor offer of prose books in 1988 (108 books for adults and 30 children books) was an obvious sign of oncoming changes in the work of publishing houses. Mass media was full of information about literature which was previously inaccessible because of the censorship; the publishing houses, however, showed no desire to embrace change. The latter may be explained by the fact that the publishing houses were still under the strict supervision of state authorities and were entitled to publish mostly those books which were listed on their thematic plans which were commonly drafted for the next two years. All in all there were only ten Latvian translations of foreign prose works and two Russian translations published in 1988. The trilogy Og bakom synger skogene (Latvian title Un mūža meži šalc; English title Beyond Sing the Woods) by the Norwegian novelist Trygve Gulbranssen (1894-1962) was published in 100,000 copies and, similarly to the novel by Mitchell, was reprinted for the third time after a break of 48 years $^{4}$, gaining immense popularity. The high demand for novels by Mitchell and Gulbranssen was confirmation of the public interest in foreign popular literature ${ }^{5}$ making publishing houses arrive at the conclusion that such publications were profitable.

Publishers tried to enrich the modest selection of popular literature: in 1989, alongside with several publications of crime fiction by local and foreign authors, the readers were introduced to the thriller novel Wind Chill Factor (publishing house Liesma, 70,000 copies, Latvian title Ledainais vējš) by the

A reprint was offered by the publishing house Liesma already in 1991 in 30,000 copies.

4 First edition in the Latvian language in 1938 (3000 copies) by Valters un Rapa. Translation performed by Lizete Skalbe. The second edition followed in 1940.

5 According to a study of the National Library of Latvia, Mitchell's works have been read by $85.3 \%$ of the respondents (Purina 1992: 24). 
American writer Thomas Gifford (1937-2000), which contained elements of the adventure, crime and fantasy genres. In the meantime the publishers had also brought to the readers two family sagas: the story of a Scottish coal miner's family The Camerons (Liesma, 30,000 copies, Latvian title Kameroni) by the American novelist Robert Crichton (1925-1993), and the bestseller The Thorn Birds (Liesma, 90,000 copies, Latvian title Dziedoṇi ērkšķu krūmā) of the Australian author Colleen McCullough (1937-2015). Its recurrent publications in the Latvian language (the last reprint in 2010 by the publishing house Zvaigzne $A B C$ ), likewise the staging of a theatre version of the novel by the Latvian National Theatre in 1993, is evidence of consistent interest readers take not only in the writings of this particular author but also in romance novels in general.

New opportunities for publishing after the restoration of indepedendence

On May 4, 1990 the Supreme Council of the Latvian SSR adopted the Declaration of the Restoration of Independence of the Republic of Latvia. Censorship was de facto abolished ${ }^{6}$ and there were no longer any political hurdles for launching entrepreneurship in the publishing industry. So, the children and youth literature department of the publishing house Liesma separated itself, establishing an independent publishing house Spriditis. Fiction was already published by sixteen publishing houses, five children's book publishers among them. Such developments accounted for a slight increase in the number and proportion of books of fiction against the total number of pieces of literature published (13.6\%, i.e. 213 prose books). However, the numbers were far from the pre-crisis level, since the newly established publishing houses were releasing one to three books (except for the publishing house Spriditis which published 43 books). A reason for such a modest output was the outdated infrastructure of the Latvian publishing industry, limited paper resources and the desire of the publishers to release books in considerable numbers of copies (the average print run for a fiction book was 42,700 copies). Diverse options were explored: cooperation with corporate business entities, which enabled access to necessary material resources; services of peripheral typographies

6 According to the decree No 87 of 10 August 1990 of the Council of Ministers of the Republic of Latvia, the Chief Administration of the Council of Ministers of the Republic of Latvia for the Protection of State Secrets in Press and other Media has been liquidated. The protection of censorship is defined also in the Constitution of the Republic of Latvia, Article 101. 
whose workload was considerably smaller and also the use of low-quality paper e.g. newsprint.

Alongside with the main specialization, the 'old' market players and also the newly established companies engaged in the publication of entertainment or high-demand literature. For illustration - the specialist publishing house Avots introduced the Russian speaking audience to two selections of crime novels by the Belgian novelist Georges Simenon (1903-1989) in 200,000 copies and also to the novel Way the Cookie Crumbles (Russian title Так кроиится печенье) by the British writer James Hadley Chase (1906-1985) in 100,000 copies, although none of these publications was on the publishing house's prospective works list for the year 1990 (Perspektīvais literatūras izlaides plāns 1990).

The crime novels by Simenon were published in Latvia during Soviet times, whereas the works by Chase were brought to the Latvian readers for the first time. It has to be noted that Chase enjoyed an enormous popularity in the Soviet Union in the 1980s and also after its collapse in the 1990s, mostly thanks to the movie Miräža (Mirage) of the Latvian director Aloizs Brenčs (1929-1998) which was based upon Chase's novel The World in My Pocket (1959). After the tremendous success of the movie in the Soviet Union and Russia in particular, authorities made attempts to moderate the gushing demand for Chase's novels by officially banning any further publications which resulted in the illegal distribution of handwritten or underground printed copies. After lifting the ban, multiple novels by Chase were published in king-size print runs. What is characteristic both of Russia and also Latvia is that Chase's novels were mostly published by non-fiction publishing houses (Pristed Beck 2013: 342). Because of the changes in the political situation, publishing houses no longer had to operate according to the assignments given them by the Soviet authorities and the savings could be spent at their own discretion. So for example, the publishing house Avots already in February 1990 deleted from its publication plan 51 and during the whole year over 90 publications.

In this regard, the newspaper publishing house Avize became a major competitor of Avots. The publishing house Avize introduced the Russian reading public to the first novel by Chase No Orchids for Miss Blandish (200,000 copies, Russian title Нет орхидейдяямисс Блендии), a book strongly criticised by George Orwell for violence and sexual content (Orwell 1944). In the time period, from 1990 to 1995, there were over twenty of Chase's novels published in Latvia, almost half of them in the Russian language, the total number of copies being 795,000.

Latvijas Valsts arhīvs, 1906. fonds, 1. apraksts, 93. lieta. 
The audience thirsting for adventure was introduced to the story of the untraceable Fantômas by Marcel Allain (1885-1969) and Pierre Souvestre (1874-1914). The first book - a reprint of the publication released by the publishing company Grämatu Draugs was brought to the readers by the publisher Avize in 20,000 copies in the fall of 1990 . A couple of months later also the publishing house Avots started the publication of a series of books about the Fantômas, however it released only three novels (210,000 copies). All in all, in the period of three years there were twenty-one books published, three of them in Russian. The books were printed on newsprint, with a thin paperback and primitive design. Mostly those were reprints of translations published by Grämatu Draugs during the first independent Republic in the 1930s, making the works subject to some formal text editing required for adjusting it to the contemporary literary language. However, the total number of copies was enormous - over half a million of copies $(557,000)$ from 1991 till 1993. The astonishing popularity of these novels during the first years of regained independence could be explained with the fact that it was a literature prohibited in the Soviet period. Paradoxically or not, but the satirical screen versions (first two movies of the trilogy Fantômas (1964-1967) by André Hunebelle (1896-1985) with the famous French actors Jean Marais and Louis de Funès in the main roles) were shown in the cinemas of Latvia already in 1967. According to the publications in press, the movies had generated heightened interest. So, for example, in a publication in the magazine Literatūra un Māksla (Literature and Art) in 1967 the film critic Elmārs Riekstiņš (1926-2000) wrote: "For week already the movie is shown in crowded cinemas and people are waiting for hours to see the Fantomas raving." (Riekstinš 1967: 15, transl. by J. Dreimane) The French criminal trilogy was repeatedly shown in the cinemas of Riga in 1990 which probably also intensified the interest in the novel. However, already in 1993 the popularity of the novel decreased and the readers desired new heroes and adventures.

A number of publishing companies who mainly specialized in the publication of popular literature emerged in the first half of the 1990s. To name the publishing house Tapals which was founded in 1991 and became known to the Latvian reading public thanks to the publications of crime fiction by Edgar Wallace (1875-1932) and Simenon. The number of books by Wallace was considerable: one book in 1990, seven books in 1991, four books in 1992, nine in 1993, thirteen in 1994 and a year later - already fourteen books. It has to be noted that the first book by Wallace released in the restored Republic of Latvia was The Forger (Russian title Фальшивомонетчик), which was published in 100,000 copies by the joint venture Apm-Cucmesc (in cooperation with the company Aнmop) and it was a reprint of the original publication by the 
publishing house Grāmatu Draugs dating back to 1936. All in all, in 1991 there were five novels by Wallace published in the Russian language with the total number of copies amounting to 500,000. The companies publishing Russian translations (Аvize, ТрансИздевейс etc.) took over not only the text of the novel, but also the design of the cover, the advertising message in old orthography and even the device of the publishing house Grämatu Draugs. In this respect the publications by Tapals prevailed in quality: although the text was taken over from earlier publications by Grämatu Draugs, the books had an original and uniform design.

The admirers of the detective fiction by the Simenon had a splendid choice a series of his novels were offered by two publishers (initially Artava, founded in 1988 as a cooperative society Atmoda, and afterwards also Tapals). Simenon was no longer published in the Russian language since there was no need for that - the local market was flooded with numerous vivid and provocatively designed Russian publications. All in all there were thirty books published in the period 1993-1995, without even considering collected works. A number of well-known French literary translators were engaged in the translation of his novels: Ieva Lase (1916-2002), Mirdza Ersa (1924-2008), Skaidrīte Jaunarāja (1934-2004), Silvija Līce (1940), Dagnija Dreika (1951), Regīna Beldava (1952), Inta Geile (Sīpolniece, 1952), Astra Skrābāne (1953), Sarmìte Madžule (1952). As was proudly recognized by both publishing houses - the contents of the series was different (Kokars 1994).

The popularity of Simenon was outpaced by the British novelist Agatha Christie, who has written more than seventy detective novels (Bloom 2000: 132) and according to the UNESCO's database of book translations, is ranked as the most translated author of the world. Similarly to Simenon, Christie was well known to Latvian and Russian readers also in Soviet times, thus, after the publishing industry had thrown off the shackles of Soviet dictate, her works experienced a real renaissance which was introduced in 1989 by the thick (556 pages) selection of novels (Liesma) which also contained her famous detective novel The Murder of Roger Ackroyd (Latvian title Rodžera Ekroida nāve). At the beginning of the 1990s Artava was the most diligent publisher of Christie's novels, all in all introducing the readers to fifteen books under the Series of Agatha Christie 8 . There were thirty two publications of Christie's works released in Latvia in the period 1990 to 1995.

The popularity of Christie's detective fiction urged Artava to look for other British detective fiction novelists. So, series of fifteen novels, introducing the readers to the adventures of the police officer Luke Thanet by Dorothy Simpson

8 From 2005 the series continued by publishing house Skarabejs. 
(1933) were released in the years from 1994 to 1995. The initial purpose of the publishing house Artava was to release works of authors banned in the Soviet period, unfortunately the necessity to survive the fierce competition forced the company to supplement its offer of Latvian original literature with popular foreign novels (Kokars 1994). Those were offered also by other publishing houses who released original literature in Latvian and high-quality translations, such as: Zinātne, Preses nams, Liesma, Daugava, Sprìdìtis. The publishing company Jumava was launched in 1994 by introducing several series of popular novels, for example Dāmu detektīvs (Ladies' Detective), Tīnu detektīvs (Teen Detective). The key of its success - diversity of publications meeting the demand of the target audience and an excellent team of translators (Amanda Aizpuriete (1956), Pēteris Bankovskis (1952), Irēna Birzvalka (1939), Silvija Brice (1958), Māra Cielēna (1954), Vinifreds Kraučis (1939-2005), Helma Lapina (1919-2009), Valda Melgalve (1955), Jānis Ramba (Elsbergs, 1969), Zane Rozenberga (1948) etc.). Like elsewhere in the world, many local publishers turned to the publication of popular novels not only for the sake of attracting a larger audience but also to have financial resources to publish elite literature.

Another publisher, Kontinents, appeared in 1993. In its first series Vakara romāns (The Evening Novel) the publishing house offered reprints of Latvian writers (Aīda Niedra (1899-1972), Zenta Mauriņa (1897-1978), Emīija Prūsa (1878-1950)) and such foreign authors as Georg Füllborn (1837-1902), Maria Corelli (1855-1924), Maurice Dekobra (1885-1973), Magda Trott (1880-1945). In comparison to other publications of popular literature, these were hardcover, unified style books which could be identified because of a specific series logo. However, soon afterwards Kontinents explored a new and at the beginning of the 1990s a completely vacant market niche - the publication of contemporary American and English bestsellers in Latvian. In the series Pasaules bestselleri (World Best-Sellers) in 1994 the local readers were introduced to the novel Once in a Lifetime (Latvian title Tikai vienreiz $d z \bar{i} v \bar{e}$ ) by Danielle Steel (1947) and to the first novel of the British writer Maria Barrett (1964), Elle (Latvian title Eleonora), in 10,000 copies each. Opposite to the usual global practice, also the books of this series were released only in hard glossy covers, wherewith the artist Vineta Dzērvìte (1968) had developed a uniform visual design: mostly those were the pictures of young, beautiful women which the potential readers associated with the protagonists of these novels.

The publishing house Rija, founded in 1994, joined in the publication of English and American bestsellers. The movie novelisations, likewise popular screened novels were released under the series Kinogalerija (Movie Gallery). Unfortunately the readers were introduced only to five novelisations, including 
Authors, Publishers and Readers of Popular Literature in Latvia

Rain Man (7000 copies, Latvian title Lietus virs) by Leonore Fleischer (1932) and A Kiss before Dying (7000 copies, Latvian title Pirmsnāves skūpsts) by Ira Levin (1929-2007). At the beginning of the 1990s such adapted screenplays were part of the book offer of other publishers as well - Grāmata, Janus, Vide, Avots - nevertheless the modest choice shows that they was not in high demand. Probably this is because novelisations do not leave so much room for the readers' imagination. Romance novels, in their turn, were published in a series titled Spogulis (Mirror) consisting of a selection of famous American authors, for example Jackie Collins (1937), Sidney Sheldon (1917-2007), Jacqueline Susann (1918-1974) and others.

In 1996 part of the employees left the publishing house Rija and started to work in a new publishing company - Juventa. Although Rija published ten books in 1996, its bankruptcy was inevitable. It may be that the reputation of the publishing house was discredited by the poor quality of its editors - as revealed by the media coverage at the time (Strazds 1995: 30-31; Linde 1995: 28-29).

The modest offer of Latvian detective fiction in the first half of the 1990s is hardly commensurable with the inflow of the works of foreign authors. The literary critic Guntis Berelis (1961) emphasized that the detective genre of the restored republic was experiencing regression and has lost much of the level of artistry achieved in Soviet times (Berelis 2011). There was not a single Latvian detective novel published in the first two years of regained independence. Two novels were presented to the readers in 1992: Sarkanais obelisks (The Red Obelisk, Avize, 10,000 copies) by Anatols Imermanis (1914-1998) and Atvèrtā seifa noslēpums (The Secret of an Open Safe, Liesma, 15,000 copies) the first novel by Jānis Ivars Stradiñš (1943). The number of new publications grew in subsequent years, nevertheless it lagged behind Soviet publications, both in terms of the interest of the potential readers and as regards reviews by literary critics. The range of prose publications, however, had almost tripled (in 1995-428), out of which approximately one forth were detective novels by foreign authors. Therefore A. Kolbergs was forced to publish his collected works himself (1993-1995, six volumes, the average print-run of volume 6000 copies) and the number of copies of separate publications did not reach the numbers common in the Soviet period.

\section{The most published romance novelists}

The productive German romance novelist Hedwig Courths-Mahler (18671950) with her 207 novels (Kunze) was highly represented in the bookstores 
of Latvia. The publication of her works was resumed in 1992 by releasing six novels - all of them reprints of the paperbacks which were brought to the readers in the middle of the 1930s. The numbers of printed copies differed a lot: for books by Arka and Krauklitis those were 4000-6000 copies; the capacity of the publishing house SIA Elita was much higher. The novel Ich will (Latvian title Mana sirds tevi sauc) by Courths-Mahler was released in 25,000 copies. From 1992 to 1995 SIA Elita published reprints of twenty three of CourthsMahler's books. Four new translations were released by Artava. Although literary critics used to refer to Courths-Mahler as a 'pulp literature classic' (Zālïtis 2005: 5) describing her books disparagingly as 'sickly-sweet syruplike readings', Courths-Mahler was the most published author of romance novels in the first years of the restored Republic of Latvia. Her works in the Latvian language are still published. The popularity of the novels by CourthsMahler can be explained by the ban on her books in Soviet years and also by the sweet memories of the elder generation of "easy reading material from one's youth" (Visockis 1995: 209). Thus, the most precise description is given by the poetess, one of the translators of English and American popular literature, Amanda Aizpuriete (1956): "Notwithstanding our constant efforts to conceal it, the majority of us have retained a love of fairytales, the "suffer and lust novels" and "Mexican soap-operas on TV." (Aizpuriete 1993: 214)

The publishing house Elita released a number of novels by other German as well as British and Russian romance authors of the end of the $19^{\text {th }}$ and the beginning of the $20^{\text {th }}$ century, such as Eufemia Adlersfeld-Ballestrem (18541941), Ethel M. Dell (1881-1939), Wilhelmine Heimburg (1848-1912), Eugenie Marlitt (1825-1887), Olga Bebutova (Оцьга Бебутова, 1879-1952), whose translations were first published in the 1930s. The design of the reprints was much the same as that of the originals - painted or photographed roses at times supplemented with a portrait of a young woman.

As for today, the romance novels or love stories by Latvian authors have not been analysed much in terms of publishing and reading habits. Thus, it is not possible to determine the most published authors among those who have or are devoting their works to romance and feelings. Aida Niedra has to be marked as one of the most productive Latvian authors whose first publications appeared already in the 1920s. She went into exile in 1944, shortly after the repeated Soviet occupation. Despite being far away from her homeland, she continued to write and her books were published by several publishing companies in exile. The publication of her novels in Latvia was resumed only in 1991 when the state-owned enterprise Litta released her exile novel Melnā magone (Black Poppy, first edition in USA by the publishing house Grāmatu Draugs, 1956) in 50,000 copies. The publishing company Austrums introduced the readers to 
her novel Salna (Frost, first edition in 1934) in 20,000 copies. The publication of her works obviously was profitable since eight novels by A. Niedra were published in 1992, one of them even twice, accounting for 210,000 copies in total. Although in the subsequent years the number of publications declined, she is regarded the most popular romantic novelist of the restored Republic of Latvia. Her novels were published by experienced publishing houses (Avots, Liesma), by newly established ones (Litta, Krūklis, Asja, Kontinents, Artava) and also by organizations whose main area of operation was not publishing, such as the academic information centre Panorāma, printing houses Rigas Paraugtipogräfija, Rota. The artistic and printing quality of books differed, however. The publications lacked the glossy uniformity which was so characteristic of the design of the publications by Kontinents, Rija or Jumava. From 1998 to 2009 the publishing house Daugava released the Rakstus (Collected Works) of A. Niedra in nine volumes.

\section{Readers of popular literature}

The dominance of popular literature in the book shelves at the beginning of the 1990s first of all is attributable to the limited access to the given literary genre during the years of Soviet occupation. There are also psychological and social considerations.

The end of the 1980s was a period of rising public awareness on the necessity of a 'normal' democratic state, however there was no certainty as to the patterns of implementing such changes or as to the very concept of normality (Stukuls-Eglitis 2002: 11-15). After regaining independence 'the old' way of living was immediately thrown away but no new one was introduced. The system of values was overruled by chaos. In a changing environment people usually feel unprotected and commonly look for a short-term escape. One of the available remedies is a captivating novel, introducing the readers to an unusual or at times an exotic environment, a charming protagonist to identify oneself with, a breathtaking plot and of course a happy ending. Although such escapism seems irrational, it has some rationale behind it - in circumstances when life becomes unbearable, forgetting reality allows one to concentrate one's thoughts and strength for the subsequent resolution of unpleasant situations and problems (Longeway 1990: 5-6).

The predominance of 'escapers' among the buyers of books at the beginning of the 1990s is proven also by the lists of the bestselling books in Latvia in 1994. The most frequently listed author was Edgar Wallace (17 times). Equally popular were the books by Agatha Christie (13 times) and Georges Simenon 
(12 times). In the category of original literature the books by A. Kolbergs were mentioned three times and the novel Piedzivojumi Francijā (Adventures in France, released in 1994 by the publishing house Preses nams; 8000 copies) by J. I. Stradiņš could also be found on the list. Romance novels (Courths-Mahler, Trotta, Sheldon), historical novels, memoirs and the works of notable Latvian poets enjoyed equal popularity with detective novels. A research of Estonian sociologists (Lõhmus 2009) reveals that the attitude towards popular culture has changed. The prevailing Soviet perception was that the consumption of popular (mass) culture was an element of bad taste and insufficient education, whereas the contemporary borders of 'high' and 'low' culture have blurred and the entertainment culture is treated as something as 'good' as the classical culture (ibid. 88). Considering the sharp decrease in the numbers of book readers and the increasing use of other media, popular literature is one of the tools for popularizing reading. The popular and elite literature is in a constant interaction and cannot subsist one without another.

\section{Conclusion}

In the first years of regained independence when state-owned and private enterprises lacked financial possibilities for the modernization of infrastructure and for the purchase of quality paper, the contents of books clearly prevailed over their form. Mostly those were plain paperback books, printed on yellowish paper, having a vivid cover as the sole eye-catching component. Frequently the elements of the visual design were adapted from the first editions published during the years of the first Republic of Latvia (1918-1940). The situation improved already in 1994 and this is confirmed by the printing quality of several series of novels. However, a glossy cover does not necessarily imply the respective quality of the text.

The broad range of publication of popular literature after the restoration of the Republic of Latvia can be considered as an evidence of the democratization of the publishing branch. Publishers trying to adapt to the wider interests of readers thus strengthen their positions in the constantly changing book market of Latvia. The assortment of books shows that Latvian readers willingly choose no only British or American authors, which dominate the global market, but also works of French and German writers. At first more attention was paid to previously inaccessible fiction than to contemporary works. Unfortunately, popular literature as such did not guarantee the stability of the publishing houses. Such publishers as Liesma, Avots, Avize, Artava, Rija, Elita have terminated their operations. The activity of the publishing house Tapals has 
Authors, Publishers and Readers of Popular Literature in Latvia

been reduced to the minimum - only a couple of books have been published after 2010. One of the reasons for their poor performance is attributable to the break in book publishing as an unrestricted business after the Soviet occupation in 1940. At the beginning of the 1990s the publishers lacked knowledge and experience when setting up a business. The contents of a book and its visual design are only a few of the components that affect the position of a publisher in the market. As for today, only the publishing house Jumava releases about two hundred of titles per year - its story of success still has to be discovered.

\author{
Jana Dreimane \\ Jana.Dreimane@lnb.lv \\ Latvijas Nacionālā bibliotēka \\ Letonikas un Baltijas centrs \\ Mūkusalas iela 3 \\ Riga \\ LATVIJA
}

\title{
References
}

Aizpuriete, A. 1993. 1992. gada jūlijs - oktobris [July 1992 - October 1993].- Karogs, $1,214$.

Berelis, G. 2011. Latviešu detektīvs. Kura nav? - http://www.goethe.de/ins/lv/rig/ $\mathrm{kul} / \mathrm{mag} / \mathrm{lit} / \mathrm{kri} / \mathrm{lv} 7157175 . \mathrm{htm}$ (30.12.2014).

Brīvā Latvija. 1987. Visa Rīga vil̦nojās vienas grāmatas dēḷ. - Brīvā Latvija: Apvienotā "Londonas Avìze" and "Latvija”, 50, 3.

Cīṇa. 1987. Vèjiem līdzi. - Cìna, 225, 4.

Glover, D., McCracken, S. 2012. Introduction: What is popular fiction? - D. Glover, S. McCracken, eds., The Cambridge Companion to Popular Fiction. Cambridge, UK; New York: Cambridge University Press.

Hofmane, L. 1992. Ko lasa krievu lasītājs Latvijā. - Dailliteratūras lasī̌̌ana 1985.-1987. Rìga: Nacionālā bibliotēka, 34-37.

Kokars, G. 1994. Tauta labprātāk lasa detektīvus. - LaukuAvīze, 63, 25.

Kunze, W. Courths-Mahler, Hedwig (eigentlich Ernestine Friederike Elisabeth). - Deutsche Biographie, http://www.deutsche-biographie.de/sfz8828.html (30.12.2014).

Latvijas izdevējdarbïbas statistika 2013. - http://dom.lndb.lv/data/obj/file/244175. pdf (8.01.2015).

Latvijas PSR prese, 1986. 1987. - Rīga: LPSR Grāmatu palāta.

Linde, J. 1995. Aiz šiem vākiem vaid papīrs. - Grāmatu Apskats, 13/14, 28-29.

Lõhmus M., Lauristin M., Siirman E. 2009. The Patterns of Cultural Attitudes and Preferences in Estonia. - Journal of Baltic Studies, 40 (1), 75-94. 
DREIMANE

Longeway, J. 1990. The Rationality of Escapism and Self-Deception. - Behavior and Philosophy, 18 (2), 5-6.

Orwell, G. 1944. Raffles and Miss Blandish. - http://gutenberg.net.au/ebooks03/ 0300011h.html\#part23 (30.12.2014).

Perspektīvais literatūras izlaides plāns / Перспективный план выпуска изданий на 1990 год. 1989. Rīga: Avots.

Pristed Beck, B. 2013. Glasnost Noire: The Soviet and Post-Soviet Publication and Reception of James Hadley Chase. - Book History, Vol. 16, 329-363.

Puriņa, A. 1992. Latviešu valodā izdotās daiḷiteratūras lasīšana (1985.-1987.). - Dailliteratūras lasī̌̌ana 1985.-1987. Rīga: Nacionālā bibliotēka, 4-25.

Riekstiņš, E. 1967. Trako ne tikai Fantomass. - Literatūra un Māksla, 37, 15.

Schlicke, P. 2000. Oliver Twist. - P. Schlicke, ed., Oxford Reader's Companion to Dickens. Oxford University Press, http://www.oxfordreference.com/view/ $10.1093 /$ acref/9780198662532.001.0001/acref-9780198662532-e0327?rskey=Px050O\&result $=11$ (30.12.2014).

Strazds, M. 1995. Kur kas kad? - Dadzis, 4, 30-31.

Stukuls-Eglitis, D. 2002. Imagining the Nation: History, Modernity, and Revolution in Latvia. University Park, PA: Penn State Press, 11-15.

Tapals/Nordik: Publishing Houses: [history and activities]. - http://www.nordik.lv/ index.php?\&57 (05.01.2015).

“TOP 50” Author. Index Translationum. -http://www.unesco.org/xtrans/bsstatexp. aspx?crit1L=5\&nTyp=min\&topN=50 (8.01.2015).

Visockis, J., Liseka, T. 1995. Mūsu lasītājiem ir laba gaume jeb Tirgus prasa no mums...: saruna ar apg. Jumava direkt. Juri Visocki un galv.red. Tamāru Liseku. - Karogs, $12,208-212$.

Zālītis, J. 2005. Pasaule uz spārna jeb Grāmatu draugs Helmars Rudzītis. - Laiks, 33, 5. 